\title{
Seed Rot and Damping-off of Alfalfa in Minnesota Caused by Pythium and Fusarium Species
}

Laurine E. Berg, College of Biological Sciences, University of Minnesota, St. Paul 55108; Susan S. Miller and Melinda R. Dornbusch, United States Department of Agriculture-Agricultural Research Service, Plant Science Research Unit, St. Paul, MN 55108; and Deborah A. Samac, ${ }^{\dagger}$ United States Department of Agriculture-Agricultural Research Service, Plant Science Research Unit, and Department of Plant Pathology, University of Minnesota, St. Paul 55108

\begin{abstract}
Globally, 15 Pythium species have been found to cause damping-off and seed rot of alfalfa, although surveys of species causing disease on alfalfa in the midwestern United States are lacking. Pathogens were isolated by a seedling baiting technique from soil samples of five alfalfa fields in Minnesota with high levels of damping-off. Of the 149 organisms isolated, 93 (62\%) were identified as Pythium spp. and 43 (29\%) were identified as Fusarium species. Pythium sylvaticum, $P$. irregulare, and $P$. ultimum var. ultimum were aggressive pathogens on germinating alfalfa seedlings. Strains of seven Pythium spp. pathogenic on soybean and corn were also pathogenic on alfalfa. The majority of the Fusarium isolates

were identified as $F$. solani and $F$. oxysporum with a low number of $F$. redolens and $F$. incarnatum-equiseti. The $F$. oxysporum and $F$. incarnatumequiseti strains were the most aggressive in causing seed and root rot. Pythium strains were sensitive to Apron XL (mefenoxam) and pyraclostrobin in vitro but efficacy varied when the fungicides were applied as a seed treatment. Seed treatments with Apron XL were more effective than treatments with Stamina against Pythium. The presence of aggressive, broadhost-range pathogens causing seed rot and damping-off suggests that new strategies are needed for managing this disease in alfalfa production systems.
\end{abstract}

Rapid and uniform seedling emergence is critical for obtaining a productive and persistent stand of alfalfa (Medicago sativa). However, a number of pathogens attack alfalfa seeds and seedlings, severely reducing plant establishment. In many locations, alfalfa seeds are planted into cold, wet soil conditions that are ideal for seed rot and damping-off to occur. A complex of soil-borne pathogens including Pythium spp., Rhizoctonia solani, Phytophthora medicaginis, and Fusarium spp. cause seed rot and damping-off of alfalfa (Hancock 1983; Leath et al. 1988) and may inflict damage to roots of surviving plants, resulting in reduced yields, decreased winter survival, and shortened stand life. Of these pathogens, Pythium spp. are considered the most damaging. Little research has focused on the role of Fusarium spp. in seed rot and damping-off of alfalfa.

Alfalfa seedlings infected by Pythium develop softened radicles and brownish lesions on cotyledons and lack root hairs. Hypocotyls and roots appear water-soaked and flaccid before seedlings collapse and die. Infection of older plants causes destruction of fine feeder roots, which interferes with nitrogen fixation, nutrient uptake from the soil, and water absorption. Injury to the root may cause root "forking" in which shallow adventitious roots form above the damaged primary root (Leath et al. 1988).

Currently, little is known about the species of Pythium attacking alfalfa in Minnesota. In California, P. ultimum was identified as a cause of damping-off in alfalfa (Hancock 1983) and was associated with rootlet diseases, along with $P$. irregulare and $P$. paroecandrum (Hancock 1985). In Missouri, damping-off of alfalfa was found to be caused by $P$. ultimum, $P$. sylvaticum, and $P$. irregulare, while reductions in root length were caused by $P$. dissotocum, $P$. acanthicum, $P$. torulosum, and $P$. rostratum (Larkin et al. 1995). In Minnesota, P. ultimum,

\section{${ }^{\dagger}$ Corresponding author. E-mail: debby.samac@ars.usda.gov}

Mention of trade names or commercial products in this publication is solely for the purpose of providing specific information and does not imply recommendation or endorsement by the U.S. Department of Agriculture. USDA is an equal opportunity provider and employer.

Accepted for publication 23 June 2017.

This article is in the public domain and not copyrightable. It may be freely reprinted with customary crediting of the source. The American Phytopathological Society, 2017.
$P$. paroecandrum, and a $P$. sylvaticum-like species were previously identified as alfalfa damping-off agents, and a culture plate assay was developed to screen alfalfa cultivars for resistance to the pathogens (Altier and Thies 1995). The identification of Pythium spp. causing disease on corn and soybean (Broders et al. 2007a; Matthiesen et al. 2016; Radmer et al. 2017; Alejandro Rojas et al. 2017; Zhang and Yang 2000), crops grown in rotation with alfalfa, raises questions about their potential to also cause disease on alfalfa.

Identification of Pythium spp. using morphological characteristics is difficult. The development of universal primers for the ribosomal ITS region have led to widespread use of this sequence for fungal and oomycete identification (Robideau et al. 2011). However, the ITS sequence of Pythium spp. can be riddled with repeats of varying length or single base insertions and deletions making alignment and comparison with reference databases difficult (Schroeder et al. 2013). The mitochondrial cytochrome oxidase $c$ subunit I gene (COI) is commonly used for identification in oomycetes. However, it exhibits less interspecies variation than is seen for the ITS region (Robideau et al. 2011), and consequently there are species that cannot be differentiated by COI. Thus, ITS and COI sequences are complementary barcodes for identifying Pythium spp.

Damping-off organisms of alfalfa are managed with cultural practices, over-seeding to offset seed and seedling losses, and fungicide seed treatments. Apron XL (active ingredient mefenoxam; R,S-2[(2,6dimethylphenyl)-methoxyacetylamino]-propionic acid methyl ester), is widely used as a seed treatment and offers protection from Pythium spp. and Phytophthora spp. However, varying levels of sensitivity to mefenoxam or its enantiomer, metalaxyl, have been found among Pythium pathogens of many field crops, including corn and soybean (Broders et al. 2007a; Matthiesen et al. 2016; Radmer et al. 2017; Zhang and Yang 2000), wheat (Cook and Zhang 1985), pea (Parke et al. 1991), sugar beet (Brantner and Windels 1998), and potato (Taylor et al. 2002). Species with reduced sensitivity to mefenoxam were first reported on alfalfa three decades ago (Hwang 1988). Currently, little is known about the response of Pythium spp. causing disease on alfalfa to Apron XL. Recently, quinone outside inhibitor (QoI) fungicides such as Stamina (active ingredient pyraclostrobin; carbamic acid,[2-[[[1-(4-chlorophenyl)$1 H$-pyrazol-3-yl]oxy]methyl]phenyl]methoxy-,methyl ester) have been labeled for managing seed and seedling diseases of alfalfa caused by Fusarium spp., R. solani, Aphanomyces euteiches, and Phytophthora medicaginis and Pythium diseases on other crops. Information on sensitivity to Stamina of Pythium spp. causing disease on alfalfa is lacking. 
The objectives of this study were to: (i) isolate and identify pathogens associated with seed rot and damping-off of alfalfa in Minnesota; (ii) evaluate the aggressiveness of these pathogens, as well as Phytopythium spp. and Pythium spp. known to be corn and soybean pathogens, for pathogenicity on alfalfa; and (iii) determine the sensitivity of Pythium spp. pathogenic on alfalfa to mefenoxam and pyraclostrobin.

\section{Materials and Methods}

Soil collection. Individual soil samples were collected in the fall of 2013 and the spring of 2014 from alfalfa production fields in Minnesota in the second or third production year as part of a survey for soilborne pathogens. Samples were collected using a soil probe to a depth of $15 \mathrm{~cm}$ in a "W" sampling pattern across each field to collect at least 16 soil cores. Each sample was sieved to remove stones and crop debris and stored at $4^{\circ} \mathrm{C}$. In preliminary assays, soil samples from five fields (Becker, St. Hilaire, Fulda, Parkers Prairie, and Waseca) were found to have a high frequency of seed rot and damping-off when used for alfalfa seed germination in growth chamber assays. Soil samples from these fields were used in this study to isolate seed rot and dampingoff pathogens.

Pathogen isolation. A rolled-towel method was used to bait pathogens from soil. Seeds of 'Saranac,' a Pythium-susceptible cultivar (Grau et al. 1989; Jones and Samac 1996), were surface sterilized by immersion in $70 \%$ ethanol for 1 min, immersion and agitation in $10 \%$ commercial household bleach for $5 \mathrm{~min}$, followed by three rinses in sterile distilled water. A 2-mm layer of each soil was laid in a 40-mm square on germination paper and moistened with sterile distilled water, then 20 surface-sterilized alfalfa seeds were placed in a $4 \times 5$ grid pattern on the soil. A second germination paper was laid over the soil, moistened thoroughly, and then both papers were rolled together and placed in a plastic bag. Six rolled towels were prepared from each soil. Groups of three bagged rolls were placed in ziplocksealed bags and incubated at either $18^{\circ} \mathrm{C}$ or $24^{\circ} \mathrm{C}$ in darkness for 3 days. Seeds and seedlings removed from the rolled-towel were rinsed in running distilled water to remove soil and surface-sterilized with the ethanol and bleach protocol described above. Seeds or seedlings recovered from each rolled-towel were placed on $1.5 \%$ water agar (WA), incubated at the baiting temperature, and observed daily for mycelial growth. Hyphal tips were removed and transferred to cornmeal agar plates (CMA; BD and Company, Sparks, MD) to obtain pure cultures. Each soil sample was baited at least twice at each temperature. Cultures on CMA were stored at $4^{\circ} \mathrm{C}$.

A collection of 18 Pythium species and three Phytopythium species isolated from infected soybean seedlings or baited from soil removed from soybean fields in Minnesota (Radmer et al. 2017) were obtained from L. Radmer, J. Kurle, and D. Malvick (University of Minnesota, Twin Cities) for testing against alfalfa.

DNA extraction. Isolates were grown in $20 \mathrm{ml}$ of V8 broth following a modified protocol from Matsumoto et al. (1999). Original V8 juice (Campbell's Soup Co., Camden, $\mathrm{NJ}$ ) was centrifuged to remove solids. The clarified juice $(100 \mathrm{ml}), 2.0 \mathrm{~g} \mathrm{CaCO}_{3}$, and $900 \mathrm{ml}$ sterile distilled water were combined and then autoclaved. Plugs cut from the edge of a growing culture were placed in the center of a 100$\mathrm{mm}$-diameter Petri plate with $20 \mathrm{ml} \mathrm{V} 8$ broth, and incubated in darkness at the baiting temperature for 4 to 7 days. Mycelium was filtered from the broth using Miracloth (EMD Chemicals, San Diego, CA), rinsed with sterile distilled water, pressed between paper towels to remove excess liquid, and freeze-dried.

Approximately $1 \mathrm{~cm}^{2}$ of lyophilized mycelium of each culture was processed using a FastDNA Kit (MP Biomedicals, Solon, $\mathrm{OH}$ ) and a Precellys 24 FastPrep machine (Bertin Technologies, Washington, DC) according to the manufacturer's instructions. DNA was stored at $-20^{\circ} \mathrm{C}$

PCR amplification, DNA sequencing and analysis. A section of ribosomal DNA including a partial $18 \mathrm{~S}$ region, ITS 1 , the $5.8 \mathrm{~S}$ region, and ITS2 was amplified using primers ITS1 (5'-TCCGTAGGT GAACCTGCGG-3') and ITS4 (5'-TCCTCCGCTTATTGATATGC $-3^{\prime}$ ). Reactions consisted of $25 \mu 12 X$ GoTaq Green (Promega Corp., Madison, WI), $0.5 \mu l$ each of $50 \mathrm{pmol} / \mu 1 \mathrm{ITS} 1$ and $50 \mathrm{pmol} / \mu 1 \mathrm{ITS} 4$, $21 \mu \mathrm{l}$ of sterile distilled water, and 50 to $350 \mathrm{ng}$ DNA. PCR parameters were $94^{\circ} \mathrm{C}$ for $2 \mathrm{~min}$, followed by 30 cycles of $94^{\circ} \mathrm{C}$ for $30 \mathrm{~s}, 55^{\circ} \mathrm{C}$ for $1 \mathrm{~min}, 72^{\circ} \mathrm{C}$ for $1 \mathrm{~min}$, with a final extension of $72^{\circ} \mathrm{C}$ for $7 \mathrm{~min}$ and a $10^{\circ} \mathrm{C}$ hold. For strains identified as Pythium species by ITS sequencing, a further amplification of the COI gene was done using the primers and conditions reported by Robideau et al. (2011). A 50- $\mu$ l reaction was run using the degenerate primers OomCox1-Levup (5'-TCAW CWMGATGGCTTTTTTCAAC-3') and FM85mod (5'-RRHWAC KTGACTDATRATACCAAA- $3^{\prime}$ ). Amplification of ITS and COI sequences was verified by gel electrophoresis using $10 \mu l$ of the reaction product on a $1 \%$ agarose gel, stained with ethidium bromide, and visualized with a GelDoc EZ Imager and Image Lab 5.1 software (BioRad, Hercules, CA). When COI amplification resulted in two bands on gel images, the electrophoresis was repeated with the remaining $40 \mu \mathrm{l}$ of each reaction to separate the bands. Both excised bands were purified according to the manufacturer's instructions with a QIAquick Gel Extraction Kit (Qiagen, Valencia, CA). The alternative reverse primer OomCox1-Levlo (5'CYTCHGGRTGWCCRAAAAACCAAA-3') (Robideau et al. 2011) was used for samples that did not amplify using FM85mod. DNA samples that did not amplify with these methods were amplified using OomCox1-Levup and OomCox1-Levlo with a gradient of annealing temperatures in a MyCycler (BioRad, Hercules, CA). Reaction parameters for this amplification were $94^{\circ} \mathrm{C}$ for $2 \mathrm{~min}$, followed by 30 cycles of $94^{\circ} \mathrm{C}$ for $1 \mathrm{~min}, 50$ to $60^{\circ} \mathrm{C}$ for $1 \mathrm{~min}$, and $72^{\circ} \mathrm{C}$ for $1 \mathrm{~min}$ with a final extension of $72^{\circ} \mathrm{C}$ for $7 \mathrm{~min}$, and a $10^{\circ} \mathrm{C}$ hold. For isolates identified as Fusarium spp. by ITS sequencing, amplification of translation elongation factor $1-\alpha(E F 1-\alpha)$ was done with the degenerate primer sequences EF1 (5'-ATGGGTAAGGARGACA AGAC-3') and EF2 (5'-GGARGTACCAGTSATCATG-3') designed by O'Donnell et al. (1998). Reactions consisted of $5 \mu 1$ 10X standard Taq reaction buffer, $1.0 \mu \mathrm{l}$ each of $50 \mathrm{pmol} / \mu \mathrm{l} \mathrm{EF1}$ and $50 \mathrm{pmol} / \mu \mathrm{l}$ EF2, $1.0 \mu \mathrm{l}$ of $10 \mathrm{mM}$ dNTPs, $0.25 \mu \mathrm{l}$ Hot Start Taq DNA polymerase (New England Biolabs, Ipswich, MA), $40.75 \mu$ l of sterile distilled water, and $1 \mu 1 \mathrm{DNA}$ (50 to $200 \mathrm{ng}$ ). Reaction parameters for this amplification were $95^{\circ} \mathrm{C}$ for $30 \mathrm{~s}$, followed by 35 cycles of $95^{\circ} \mathrm{C}$ for $30 \mathrm{~s}$, $55^{\circ} \mathrm{C}$ for $30 \mathrm{~s}$, and $68^{\circ} \mathrm{C}$ for $1 \mathrm{~min}$ with a final extension of $68^{\circ} \mathrm{C}$ for $7 \mathrm{~min}$, and a $10^{\circ} \mathrm{C}$ hold. All PCR products were purified with a QIAquick PCR Purification Kit (Qiagen) according to the manufacturer's instructions. DNA concentrations were quantified with Nanodrop 2000 software and spectrometer (Thermo Fisher Scientific, Minneapolis, MN). Amplified and purified DNA samples were stored at $-20^{\circ} \mathrm{C}$.

Amplified DNA samples were sequenced in both directions by the University of Minnesota Biomedical Genomics Center (St. Paul, MN). Sequencher (version 4.10.1, Gene Codes Corporation, Ann Arbor, MI) base-calling software was used to align chromatograms, and generate consensus FASTA sequences for comparison with the NCBI nucleotide nonredundant $(\mathrm{nr} / \mathrm{nt})$ collection for identification of Pythium spp. The BLAST parameters for identification were $e$-values of 0.0 , maximum identity match of $99 \%$ or greater with no gaps, and a query coverage of $98 \%$ or greater. For identification of Fusarium spp., the consensus FASTA sequences for both the ITS region and EF1- $\alpha$ were use for BLAST analysis on the Fusarium MLST website (http://www. westerdijkinstitute.nl/fusarium/) utilizing polyphasic identification as recommended by O'Donnell et al. (2015).

Pathogenicity assays. A culture plate method (Altier and Thies 1995) was used to test pathogenicity and aggressiveness of 21 Pythium strains baited from alfalfa field soils selected based on origin of the soil sample and species identification. In addition, 18 Pythium and three Phytopythium strains previously tested for pathogenicity on soybean and corn seedlings (Radmer et al. 2017) were tested for pathogenicity on alfalfa seeds and seedlings. Inoculum was prepared from pure cultures stored on CMA at $4^{\circ} \mathrm{C}$. Fresh subcultures on CMA were incubated at $21^{\circ} \mathrm{C}$ until mycelia covered the surface of the plate, then 3-mm plugs from the edge of the colony were transferred to the centers of $100-\mathrm{mm}$-diameter plates of $1.5 \%$ WA. Plates were incubated at $21^{\circ} \mathrm{C}$ for 3 to 7 days until the agar surface was covered with mycelium. Twenty-five 'Saranac' alfalfa seeds were surface-sterilized with ethanol and bleach, as described above, and placed on the surface of each plate. Uninoculated plates with 25 seeds served as controls. The plates were incubated in a growth chamber for 5 days at $21^{\circ} \mathrm{C}$, with a $16-\mathrm{h}$ photoperiod. The experiment was arranged as a randomized complete 
block with three replicates per isolate with each replicate as a block and the experiment was done twice. Seeds and seedlings were rated for disease severity on a 1 to 5 scale with $1=$ the primary root free of necrosis; $2=$ the primary root tip necrotic, but firm; $3=$ the primary root tip soft and rotted; $4=$ the seed germinated with an emerged, rotted radicle; and $5=$ seeds ungerminated and rotted (Altier and Thies 1995). Control plates were used to calculate the expected seed germination percentage for each trial, and to differentiate pathogen-killed seed from seeds on the inoculated plates that failed to germinate for other reasons. Calculated killed-seed values were corrected to zero if negative. An Average Severity Index (ASI) modified from Altier and Thies (1995) was calculated using the following formula:

$$
\begin{aligned}
\mathrm{ASI}= & \{[(\text { number in class } 5-\text { number of ungerminated } \\
& \text { seeds in control }) \times 5]+(\text { number in class } 4 \times 4) \\
+ & (\text { number in class } 3 \times 3)+(\text { number in class } 2 \times 2) \\
+ & \text { number in class } 1\} / \text { expected number of } \\
& \text { germinated seeds. }
\end{aligned}
$$

Pathogenicity was defined as an ASI $\geq 3$.0.

The culture plate method was also used for testing pathogenicity and aggressiveness of seven Fusarium isolates of different species baited from soil. The assay was done as described above except that the
Fusarium strains were cultured on PDA for production of culture plugs, then cultured on WA for 7 days, and seeds were incubated in a lighted growth chamber at $24^{\circ} \mathrm{C}$ for 7 days. Symptoms were rated on the same 1 to 5 scale as for the Pythium plate assay. Disease severity data were compared using the Kruskal-Wallis test and Dunn's multiple comparison test by GraphPad Prism7 analysis software (GraphPad Software, La Jolla, CA).

An infested soil assay was developed to evaluate seed root and seedling damping-off caused by nine Pythium strains and to compare results to the culture plate method. To prepare the soil, $250 \mathrm{~cm}^{3}$ of a peat-based potting mix (Sungro LC8, SunGrow Horticultural Distribution, Agawam, MA) was mixed with $5 \mathrm{~g}$ corn meal, and autoclaved for $20 \mathrm{~min}$. Each strain of Pythium was cultured on a $15 \times 100 \mathrm{~mm} \mathrm{CMA}$ plate at $21^{\circ} \mathrm{C}$ for 7 days, homogenized in a blender in a total of 1 liter sterile water, and $125 \mathrm{ml}$ of homogenate added to the soil mix. Approximately $50 \mathrm{~cm}^{3}$ of soil mix was placed in a $3 \times 6 \mathrm{~cm}$ pot. Twenty five alfalfa seeds were placed in each pot, covered with uninfested potting mix, and placed in a lighted growth chamber at $21^{\circ} \mathrm{C}$. Controls consisted of pots of 25 seeds in cornmeal-amended soil treated with homogenate made using an uninoculated CMA plate. The experiment was arranged as a randomized complete block with four replicates

\begin{tabular}{|c|c|c|c|c|c|c|}
\hline \multirow[b]{2}{*}{ Species name } & \multicolumn{6}{|c|}{ Location } \\
\hline & Becker & Fulda & Parkers Prairie & St. Hilaire & Waseca & Total \\
\hline Pythium acrogynum & & & & & 1 & 1 \\
\hline Pythium attrantheridium & & 2 & 1 & 5 & 1 & 9 \\
\hline Pythium carolinianum & & & & & 1 & 1 \\
\hline Pythium heterothallicum & 1 & 2 & & 13 & 12 & 28 \\
\hline Pythium irregulare & 2 & & 1 & & & 3 \\
\hline Pythium pleroticum & & 1 & & & & 1 \\
\hline Pythium schmitthenneri & & & & & 2 & 2 \\
\hline Pythium sylvaticum & 20 & 5 & 8 & 3 & & 36 \\
\hline Pythium ultimum var. ultimum & & & & & 2 & 2 \\
\hline Fusarium incarnatum equiseti & & 1 & & & & 1 \\
\hline Fusarium oxysporum & & 2 & 2 & 6 & 4 & 14 \\
\hline Fusarium redolens & & & & 1 & & 1 \\
\hline Fusarium solani & 2 & 2 & 2 & 4 & 9 & 18 \\
\hline Fusarium tricinctum & & & & 1 & 5 & 6 \\
\hline
\end{tabular}
per isolate with each replicate as a block. After 5 days, percent seed germination was assessed. Percentages were arcsine square root transformed before analysis by one-way ANOVA. Mean separation was

Table 1. Frequency of Pythium and Fusarium species isolated from five Minnesota field soil samples with a high incidence of damping-off

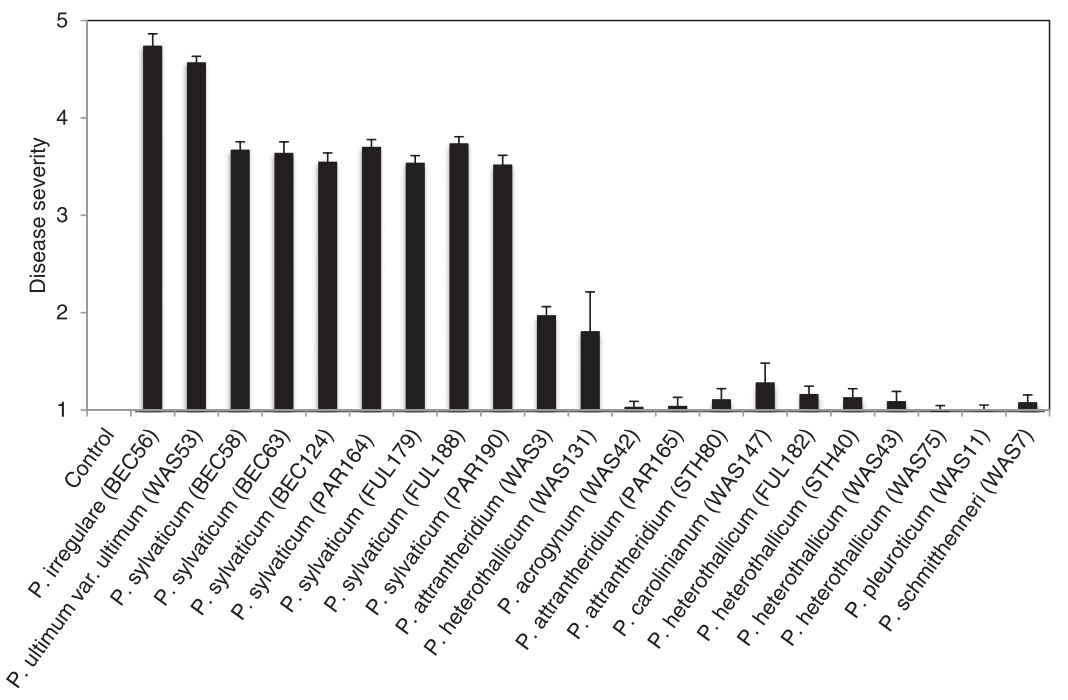

Fig. 1. Pathogenicity of Pythium species baited from field soil with high levels of seed rot and damping off of alfalfa. Average disease severity of each strain was assayed in a culture plate assay with 25 seeds in each plate with three replicate plates for each strain. After 5 days incubation at $21^{\circ} \mathrm{C}$, each seed was scored on a 1 to 5 scale: $1=$ the primary root free of necrosis; $2=$ the primary root tip necrotic, but firm; $3=$ the primary root tip soft and rotted; $4=$ the seed germinated with an emerged, rotted radicle; $5=$ seeds ungerminated and rotted. Data are the average disease severity and standard deviation per replicate averaged over two experiments $(n=6)$. Controls lacking the pathogen had an average disease severity score of 1 . 
tested by Tukey's multiple comparison test using GraphPad Prism7 analysis software.

Fungicide efficacy and sensitivity. Using the culture plate method, 17 pathogenic Pythium strains were tested against the fungicides Apron XL (active ingredient mefenoxam) and Stamina (active ingredient pyraclostrobin) applied as commercial seed coatings. Treated 'Vernal' alfalfa seeds were obtained from Summit Seed Coatings (Caldwell, ID). The seed coatings were commercially prepared in a Rotostat seed-coating machine and consisted of calcium carbonate at $0.34 \mathrm{~g} / \mathrm{g}$ of alfalfa seed with fungicides at the recommended rates: Apron XL at 0.64 fluid ounces per 100 pounds of seed $(18.9 \mathrm{ml}$ per $45.4 \mathrm{~kg})$ or Stamina at 3.1 fluid ounces per 100 pounds of seed $(92 \mathrm{ml}$ per $45.4 \mathrm{~kg}$ ). Seeds coated with calcium carbonate without fungicide were used as controls. Seeds and seedlings were rated for disease severity using the same 1 to 5 scale used in the pathogenicity assays. Three replicate plates of each strain, 25 seeds/plate, were tested in each trial, and each trial was repeated. The percentage of protected plants $(\% \mathrm{P})$ was calculated as: $\%$
$\mathrm{P}=[($ number in class $1+$ number in class 2$) /$ number of expected germinated seeds $] \times 100$.

Ten strains were assessed for sensitivity to pyraclostrobin (BASF Corp., Research Triangle Park, NC) in the presence of salicylhydroxamic acid (SHAM; Aldrich Chem. Co., Milwaukee, WI), which blocks the alternative oxidase pathway. CMA was amended with $1.0 \mu \mathrm{g} / \mathrm{ml}, 0.1 \mu \mathrm{g} / \mathrm{ml}$, or $0.01 \mu \mathrm{g} / \mathrm{ml}$ pyraclostrobin with $50 \mu \mathrm{g} / \mathrm{ml}$ or $100 \mu \mathrm{g} / \mathrm{ml}$ SHAM (dissolved in methanol). Two controls were used for comparison with the fungicide: CMA amended with SHAM; or CMA with $2 \mathrm{ml} /$ liter methanol. A 3.5-mm diameter plug from the edge of a 2- to 3-day-old colony of Pythium on CMA was transferred to the center of WA plates amended with fungicide and control plates. The experiment was arranged as a randomized complete block. There were three replications of each fungicide concentration and control and the experiment was done twice. Colony growth was determined as the average of two diameters measured at right angles to each other after $48 \mathrm{~h}$ incubation at $21^{\circ} \mathrm{C}$ in the dark. Growth reduction and fungicide concentration causing $50 \%$ relative

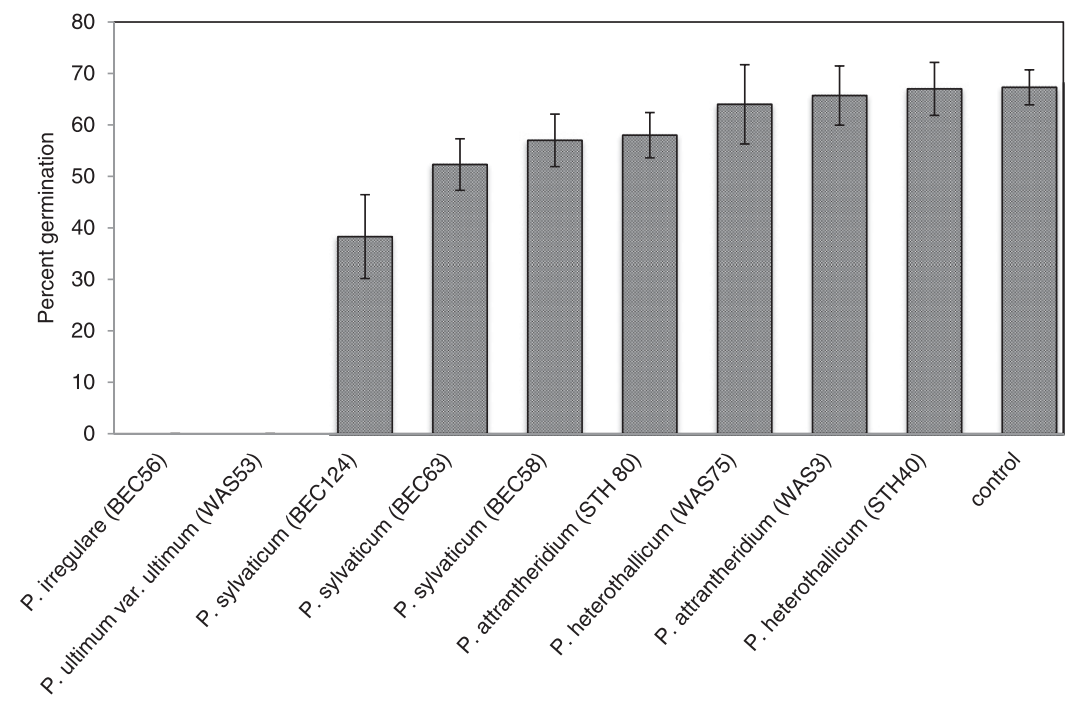

Fig. 2. Percent germination of alfalfa seeds in soil infested with Pythium species baited from soil with high levels of seed rot and damping off of alfalfa. Sterilized potting mix was infested with a mycelial homogenate and planted with 25 alfalfa seeds in each pot. Percent germination compared with uninfested soil was determined after 5 days incubation at $21^{\circ} \mathrm{C}$. Data are average percent germination and standard deviation in each pot $(n=12)$. No germination was observed for soil infested with $P$. irregulare and $P$. ultimum var. ultimum.

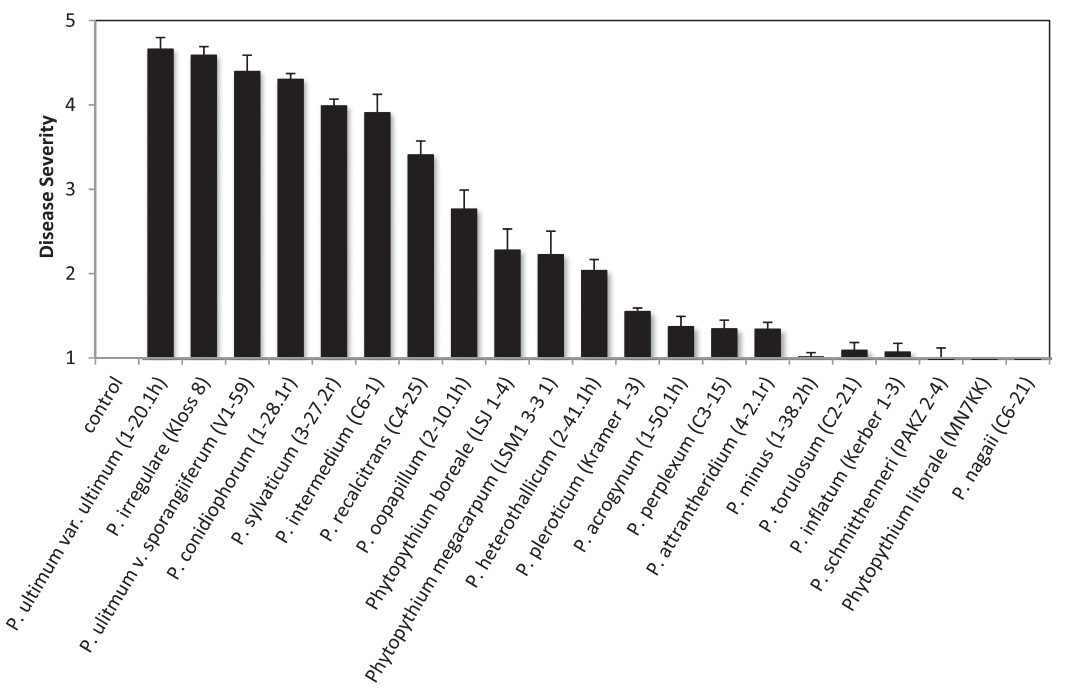

Fig. 3. Pathogenicity on alfalfa of Pythium and Phytopythium species from Minnesota pathogenic on corn and soybean. Average disease severity of each strain was assayed in a culture plate assay with 25 seeds in each plate with three replicate plates for each strain. After 5 days incubation at $21^{\circ} \mathrm{C}$, each seed was scored on a 1 to 5 scale as described for Fig. 1. Data are the average disease severity and standard deviation per replicate. Controls lacking the pathogen had an average disease severity score of 1. 
reduction of mycelial growth $\left(\mathrm{EC}_{50}\right)$ was determined following the method of Taylor et al. (2002). Three strains were tested for sensitivity to pyraclostrobin in the absence of SHAM using CMA amended with 10,20 , or $40 \mu \mathrm{g} / \mathrm{ml}$ pyraclostrobin.

The same 10 Pythium strains were tested for sensitivity to Apron XL (Syngenta Agrochemical Company, Basel, Switzerland). CMA was amended with the commercial fungicide preparation so that media contained mefenoxam at $1.0 \mu \mathrm{g} / \mathrm{ml}, 0.1 \mu \mathrm{g} / \mathrm{ml}$, or $0.01 \mu \mathrm{g} / \mathrm{ml}$ and growth was compared with CMA controls without fungicide. Plates were inoculated, incubated, and colony growth determined as above.

\section{Results}

Isolation and identification of seed rot and dampingoff pathogens. A total of 149 isolates were baited from soil samples obtained from five alfalfa fields in Minnesota with high levels of alfalfa seed rot and seedling damping-off. Of these, 93 isolates $(62 \%)$ were identified as Pythium using ITS and/or COI sequence similarity to accessions in the NCBI database and 76 isolates were identified to species. The remaining isolates could not be identified unambiguously to species. Pythium sylvaticum was most frequently isolated, followed in abundance by $P$. heterothallicum, $P$. attrantheridium, P. irregulare, P. ultimum var. ultimum, P. schmitthenneri, P. acrogynum, $P$. carolinianum, and $P$. pleroticum (Table 1). The incubation temperature at which baiting was done influenced the species recovered. $P$. ultimum var. ultimum, $P$. schmitthenneri, and $P$. pleroticum were recovered only from low temperature incubation. The single $P$. carolinianum strain was isolated from incubation at the higher temperature. All other species were isolated at both incubation temperatures.

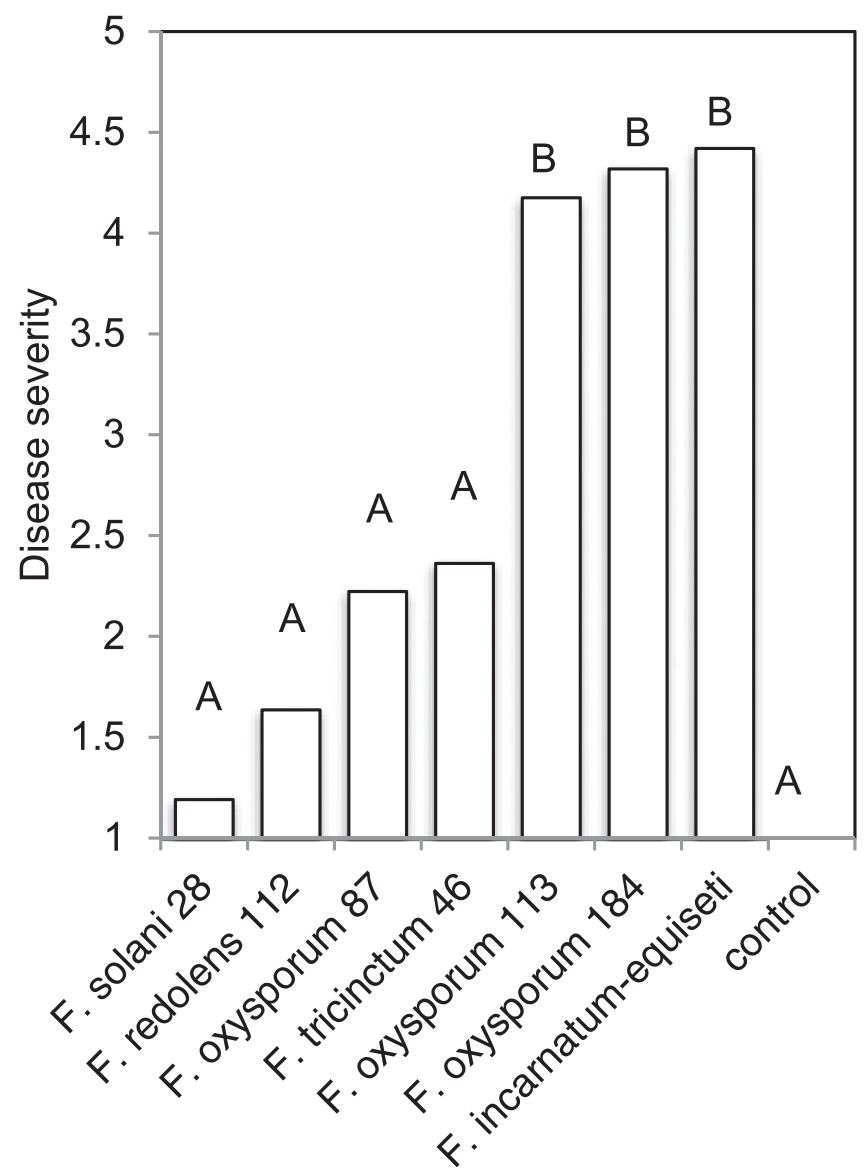

Fig. 4. Pathogenicity of Fusarium species baited from soil with high levels of seed rot and damping off of alfalfa. Average disease severity of each strain was assayed in a culture plate assay with 25 seeds in each plate with three replicate plates for each strain. After 7 days incubation at $24^{\circ} \mathrm{C}$, each seed was scored on a 1 to 5 scale as described in Fig. 1. Data are the average disease severity per replicate. Controls lacking the pathogen had an average disease severity score of 1 . Bars with a different letter are significantly different at $P<0.05$.
Non-Pythium isolates accounted for $38 \%$ of the organisms; 43 of the 57 isolates were identified by ITS sequence as Fusarium. Multilocus sequence typing with ITS and EF1- $\alpha$ sequences identified five species: $F$. solani was the most frequently isolated followed by $F$. oxysporum, $F$. tricinctum, $F$. redolens, and $F$. incarnatum-equiseti (Table 1). Soil source influenced the number of total species identified. The Waseca soil sample had the highest number of species with six Pythium spp. and three Fusarium spp. while the Becker soil had the lowest number of species with three Pythium spp. and one Fusarium spp.

Pathogenicity assays. Average disease severity (ASI) ratings $\geq 3$ in the culture plate assay indicated that eight strains, $P$. ultimum var. ultimum, $P$. irregulare, and six $P$. sylvaticum strains, were pathogenic on alfalfa (Fig. 1). The P. ultimum var. ultimum and $P$. irregulare strains were significantly more pathogenic $(P<0.001)$ than $P$. sylvaticum strains and were very aggressive seed rot pathogens while the $P$. sylvaticum caused both seed rot and root rot of seedlings. One strain of $P$. attrantheridium (WAS3) and $P$. heterothallicum (WAS131) caused moderate amounts of seed rot and root rot of seedlings (ASI $>$ 1.5). Ten strains, four $P$. heterothallicum, two $P$. attrantheridium, and one strain each of $P$. carolinianum, $P$. schmitthenneri, $P$. pleroticum, and $P$. acrogynum, caused low amounts of seed rot (Fig. 1).

The results of the plate assays were compared with those of with nine strains in growth chamber experiments in which seedlings were grown in Pythium-infested potting medium. The P. irregulare (BEC56) and $P$. ultimum var. ultimum (WAS53) strains caused severe seed rot, with no germinated seeds observed (Fig. 2), which was also observed in the culture plate assay. The $P$. sylvaticum strains and $P$. attrantheridium STH80 caused a moderate amount of seed rot, reducing germination by 17 to $49 \%$ compared with the control treatment. Although the three $P$. sylvaticum strains tested had a similar disease phenotype in the plate assay, strain BEC124 caused significantly more seed rot than strain BEC58 in the soil assay $(P=0.0332)$. The $P$. attrantheridium WAS3 and $P$. heterothallicum strains were not significantly different from the control treatment. A low amount of seed rot caused by $P$. attrantheridium and $P$. heterothallicum strains was observed in the culture plate assay.

Pythium and Phytopythium strains from Minnesota soils isolated by baiting using soybean or isolated from infected soybean seedlings (Radmer et al. 2017) were tested using the culture plate assay to determine their ability to cause disease in alfalfa. Seven of the 21 strains assayed were found to be aggressive alfalfa pathogens with an ASI $\geq 3.0$ (Fig. 3). These seven strains were also the most aggressive on both soybean and corn in seedling assays (Radmer et al. 2017). The P. ultimum var. ultimum, $P$. irregulare, and $P$. ultimum var. sporangiiferum strains were found to be alfalfa seed rot pathogens. The $P$. conidiophorum and $P$. sylvaticum strains caused seed rot and root rot of alfalfa seedlings while the $P$. intermedium, $P$. recalcitrans, and $P$. oopapillum strains primarily caused alfalfa seedling root rot. The other species assayed caused low amounts of seed rot (Fig. 3). This is the first observation of P. intermedium, $P$. recalcitrans, $P$. oopapillum, Phytopythium boreale, and $P$. megacarpum causing disease on alfalfa.

The culture plate assay was used to evaluate pathogenicity and aggressiveness of Fusarium strains isolated by baiting from soil samples. Seed colonization and seed rot and root stunting and root necrosis were observed. Fusarium solani, $F$. redolens, $F$. tricinctum, and $F$. oxysporum 87 caused low amounts of seed rot (Fig. 4) and at 5 days after plating were sporulating on infected seeds, but did not cause root necrosis. In contrast, $F$. oxysporum 113 and 184 as well as $F$. incarnatum-equiseti 180 were significantly different $(P<0.001)$ than the control and other strains and caused seed rot, root stunting, and root necrosis.

Fungicide efficacy and sensitivity of Pythium strains to fungicides. Fungicide efficacy toward 17 Pythium strains pathogenic on alfalfa was tested using alfalfa seeds with a commercial application of Stamina (pyraclostrobin) or Apron XL (mefenoxam) at the recommended rates. Apron XL was effective against seven strains when used as a seed treatment but for 10 strains there were fewer than $75 \%$ protected seeds (Fig. 5). The two most aggressive seed rot pathogens in the culture plate assay, P. irregulare (BEC56) and P. ultimum var. ultimum (WAS53), had the lowest percentage of protected seeds. Efficacy of Stamina as a seed treatment in the in vitro assay varied from 0 to $79 \%$ protected seeds. 
Fungicide sensitivity was tested by measuring mycelial growth inhibition on CMA amended with Apron XL. $\mathrm{EC}_{50}$ values were between 0.043 and $0.132 \mu \mathrm{g} / \mathrm{ml}$ mefenoxam (Table 2). We observed reduced density of mycelium at higher fungicide concentrations, a reduction in growth that was not fully captured by radial growth. $\mathrm{EC}_{50}$ values for the active ingredient in Stamina, pyraclostrobin, in the presence of $50 \mu \mathrm{g} / \mathrm{ml} \mathrm{SHAM} \mathrm{to} \mathrm{inhibit} \mathrm{the} \mathrm{alternative} \mathrm{oxidase} \mathrm{pathway} \mathrm{ranged}$ from 0.448 to $0.885 \mu \mathrm{g} / \mathrm{ml}$ pyraclostrobin (Table 2). Growth inhibition by $50 \mu \mathrm{g} / \mathrm{ml}$ SHAM ranged from 74 to $84 \%$. Similar $\mathrm{EC}_{50}$ values were obtained when $100 \mu \mathrm{g} / \mathrm{ml}$ SHAM was added to the medium to obtain 36 to $51 \%$ growth reduction (data not shown). When SHAM was omitted from the medium, the $\mathrm{EC}_{50}$ values for the three strains tested-P. ultimum var. ultimum (WAS53), P. sylvaticum (FUL188), and P. sylvaticum (PAR190) —were $15.8 \mu \mathrm{g} / \mathrm{ml}, 20.9 \mu \mathrm{g} / \mathrm{ml}$, and $24.1 \mu \mathrm{g} / \mathrm{ml}$, respectively, indicating that these Pythium strains utilize the alternative oxidase pathway as a means of tolerating pyraclostrobin.

\section{Discussion}

Globally, 15 species of Pythium have been reported to cause seed rot and damping-off of alfalfa (Malvick and Grau 2015). However, information on Pythium spp. diversity on alfalfa in the midwestern United States, specifically Minnesota, is limited. This study identified highly aggressive $P$. irregulare, $P$. ultimum var. ultimum, and $P$. sylvaticum strains from field soils with high levels of damping-off that caused seed rot and root rot of alfalfa. Additionally, highly aggressive $F$. oxysporum and $F$. incarnatum-equiseti strains causing alfalfa seed rot and root necrosis were isolated from these field soils. Aggressive alfalfa pathogens were also identified in a set of Pythium spp. previously identified as pathogens of corn and soybean. Specifically, $P$. conidiophorum, $P$. intermedium, and $P$. recalcitrans isolated from soybean or baited from soil of soybean fields (Radmer et al. 2017) were demonstrated to cause disease in alfalfa for the first time. These strains, as well as soybean/corn strains of $P$. ultimum var. ultimum, $P$. irregulare, $P$. ultimum var. sporangiiferum, and $P$. sylvaticum were the most aggressive against alfalfa in our studies and against soybean in a previous study (Radmer et al. 2017). Additionally, strains of Phytopythium boreale and $P$. megacarpum, which infect corn and soybean, were found to cause alfalfa seed rot in a culture plate assay. An extensive survey for oomycetes associated with soybean seedlings in 11 states within the United States and in Ontario, Canada, found Pythium spp. to be the most prevalent, with $P$. sylvaticum, $P$. heterothallicum, $P$. ultimum, $P$. oopapillum, $P$. dissotocum, and $P$. irregulare to be the most frequently isolated across locations (Alejandro Rojas et al. 2017). These species tended to be the most aggressive in seed rot and root rot assays. We found that all of these species, except $P$. dissotocum, which was not part of our study, to cause seed rot and damping-off of alfalfa. The wide distribution of highly aggressive, broad-host-range strains of Pythium indicates that crop rotation may have limited effectiveness for reducing pathogen populations that can cause significant seed rot and seedling root rot of the most important crop plants in the midwestern United States.

Nine Pythium spp. were isolated from five alfalfa field soils using a baiting technique. Three of these, P. irregulare, P. ultimum var. ultimum, and $P$. sylvaticum, were highly aggressive on alfalfa in culture plate assays. Pathogenicity of these strains was confirmed using an artificially infested soil assay. The P. irregulare and P. ultimum var. ultimum strains

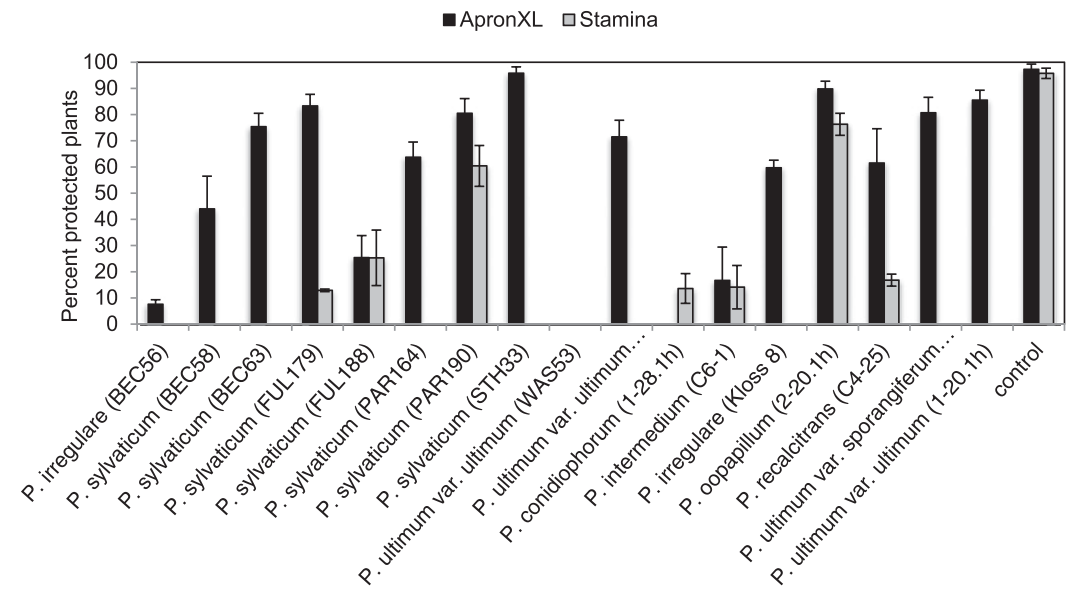

Fig. 5. Percentage of plants protected from pathogenic Pythium species by Apron XL and Stamina seed treatments. Each strain was assayed in a culture plate assay with 25 treated seeds in each plate with three replicate plates for each strain. Control plates were without pathogen inoculation. After 5 days incubation at $21^{\circ} \mathrm{C}$, each seed was scored on a 1 to 5 scale as described for Fig. 1. Protected plants had a score of 1 or 2 . No protected plants were observed for seeds lacking fungicide treatments. Data are the average percentage of protected plants and standard deviation per replicate.

Table 2. Concentrations of mefenoxam and pyraclostrobin that reduced growth of pathogenic Pythium strains by $50 \%\left(\mathrm{EC}_{50}\right)$

\begin{tabular}{|c|c|c|c|c|}
\hline Strain & Species & Mefenoxam EC $\mathrm{EC}_{50}(\mu \mathrm{g} / \mathrm{ml})^{\mathrm{a}}$ & Pyraclostrobin $\mathrm{EC}_{50}(\mu \mathrm{g} / \mathrm{ml})^{\mathrm{b}}$ & $\%$ Growth inhibition by SHAM \\
\hline BEC56 & Pythium irregulare & 0.127 & 0.890 & 75 \\
\hline BEC58 & Pythium sylvaticum & 0.132 & 0.652 & 79 \\
\hline BEC63 & Pythium sylvaticum & 0.112 & 0.541 & 84 \\
\hline FUL179 & Pythium sylvaticum & 0.070 & 0.491 & 78 \\
\hline FUL188 & Pythium sylvaticum & 0.075 & 0.448 & 78 \\
\hline PAR164 & Pythium sylvaticum & 0.073 & 0.499 & 78 \\
\hline PAR190 & Pythium sylvaticum & 0.077 & 0.506 & 82 \\
\hline STH33 & Pythium sylvaticum & 0.063 & 0.501 & 74 \\
\hline WAS126 & Pythium ultimum var. ultimum & 0.052 & 0.532 & 77 \\
\hline WAS53 & Pythium ultimum var. ultimum & 0.043 & 0.496 & 78 \\
\hline
\end{tabular}

\footnotetext{
${ }^{a}$ Apron XL was added to CMA to achieve mefenoxam concentrations of $1.0 \mu \mathrm{g} / \mathrm{ml}, 0.1 \mu \mathrm{g} / \mathrm{ml}, 0.01 \mu \mathrm{g} / \mathrm{ml}$, and $0 \mu \mathrm{g} / \mathrm{ml}$.

${ }^{\mathrm{b}}$ Pyraclostrobin was added to CMA at $1.0 \mu \mathrm{g} / \mathrm{ml}, 0.1 \mu \mathrm{g} / \mathrm{ml}, 0.01 \mu \mathrm{g} / \mathrm{ml}$, and $0 \mu \mathrm{g} / \mathrm{ml}$. Salicylhydroxamic acid (SHAM) was added at $50 \mu \mathrm{g} / \mathrm{ml}$ to inhibit the action of the alternative oxidase pathway.

${ }^{\mathrm{c}}$ Growth inhibition on CMA with SHAM at $50 \mu \mathrm{g} / \mathrm{ml}$ compared with CMA amended with $2 \mathrm{ml} /$ liter methanol.
} 
primarily caused seed rot, while the $P$. sylvaticum strains caused seed rot and seedling root rot. Stelfox and Williams (1980) noted that $P$. sylvaticum is moderately virulent to alfalfa in the cotyledon stage, and the current study demonstrated that it is a significant pathogen in vitro and when inoculated into soil. The culture plate assay has the advantage of discriminating aggressiveness of isolates and the tissue attacked. It was used previously to characterize alfalfa cultivars for resistance to Pythium spp. (Altier and Thies 1995). A similar assay was used to evaluate pathogenicity of Pythium strains on corn and soybean (Broders et al. 2007a; Zhang and Yang 2000). Not all of the Pythium spp. isolated by the baiting technique were aggressive pathogens on alfalfa. Interactions of Pythium spp. with plants range across a spectrum from beneficial to pathogenic (McLeod et al. 2009). Some Pythium spp. are saprophytes (Uzuhashi et al. 2010), while others act as competitors and mycoparasites, including on other Pythium spp.

We adapted the culture plate assay for evaluating pathogenicity of the five Fusarium spp. isolated by baiting from Minnesota field soils with high levels of seed rot and damping-off of alfalfa. Fusarium spp. were recognized early as part of the seed rot and damping-off disease complex disease complex on alfalfa (Hancock 1983; Schmitthenner 1964), but information on pathogenicity and aggressiveness of individual strains has been lacking. The most aggressive strain identified in this study was the $F$. incarnatum-equiseti strain isolated from the Fulda field soil, which caused seed rot and root necrosis of seedlings. Previously, F. equiseti was identified as an infrequent member of the alfalfa crown rot complex (Pegg and Parry 1983). Recently, this species was clustered with morphologically similar $F$. incarnatum to form the $F$. incarnatum-equiseti species complex (O'Donnell et al. 2012). F. oxysporum causes crown rot of alfalfa (Ariss et al. 2007) and vascular wilt of alfalfa (Leath et al. 1988). We believe this is the first observation of seed rot and seedling root rot of alfalfa caused by $F$. incarnatumequiseti and $F$. oxysporum. The results of our experiments suggest that Fusarium spp. have been overlooked as causal agents of seed rot and seedling root rot of alfalfa.

The culture plate assay was useful for evaluating efficacy of seed treatments. A similar assay was used to evaluate fungicide seed treatments on corn seeds challenged with Fusarium spp. (Broders et al. 2007b; Munkvold and O'Mara 2002). Alfalfa seeds commercially treated with the recommended rates of Apron XL or Stamina were tested with each of the Pythium strains pathogenic on alfalfa. For six out of 10 strains tested with the Apron XL treated seeds, the percentage of protected plants was $<75 \%$, indicating that the seed treatment was not highly effective in reducing disease symptoms. The seed treatment was least effective against the more aggressive seed rot strains, $P$. ultimum var. ultimum (WAS53) and $P$. irregulare (BEC56), and more effective against the $P$. sylvaticum strains causing both seed rot and root rot (Fig. 5). However, we observed all strains to have low $\mathrm{EC}_{50}$ values in the mefenoxam-amended medium, indicating that they are sensitive to Apron XL. The results of the plate assay suggest that highly aggressive seed rot strains escape control by the seed treatment, perhaps by rapid colonization of the seed interior, which would impact seed germination and seedling establishment. Fibrous feeder roots of mature alfalfa plants are vulnerable to attack by Pythium during periods of wet cool weather. Breeding for resistance to Pythium diseases could enhance initial stand establishment and mature plant productivity.

The phenylamide fungicides, including metalaxyl and mefenoxam, were introduced in the 1970s and were used widely for management of diseases caused by oomycetes. These fungicides have a very specific mode of action, inhibiting pathogen ribosomal RNA polymerases, making them at high risk for development of resistance in pathogen populations. Early studies on the effect of metalaxyl on Pythium pathogens of alfalfa found strains that varied in sensitivity to the fungicide (Hwang 1988; Larkin et al. 1995). Seed treatments with metalaxyl were found to provide incomplete protection against infection by Pythium spp. (Edmisten et al. 1988), while drenches significantly increased protection (Larkin et al. 1995; 1996). It is not clear if repeated use of phenylamide fungicide seed treatments have increased the populations of Pythium spp. with tolerance to the fungicides. The $\mathrm{EC}_{50}$ values for mefanoxam vary widely for Pythium strains isolated from soybean (Radmer et al. 2017) and potato (Taylor et al. 2002), although most isolates are considered sensitive.
The QoI fungicide Stamina has recently been labeled for use on alfalfa seed. These fungicides act by blocking electron transport at the mitochondrial cytochrome oxidase $b c_{1}$ complex thereby inhibiting respiration (Venancio et al. 2003). The Stamina seed coating was ineffective against most of the strains in the plate assay. However, the in vitro growth assays of Pythium strains in pyraclostrobin-amended media found that alfalfa strains are sensitive if cultured in the presence of SHAM, which inhibits the alternative oxidase pathway (Table 2). In the absence of SHAM, we found strains to have high $\mathrm{EC}_{50}$ values approximately 40 fold higher than in the presence of SHAM. This indicates that Pythium strains can tolerate QoI fungicides by use of the alternative oxidase pathway. We assume the seed treatment was ineffective due to the activity of the alternative oxidase pathway. High $\mathrm{EC}_{50}$ values for Pythium spp. have been reported in the presence of SHAM (Matthiesen et al. 2016), suggesting that insensitivity to QoI fungicides occurs in nature. Insensitivity to the QoI fungicides is seen in some pathogens as a result of mutations at the target-binding site (Bartlett et al. 2002). The mechanism of insensitivity in Pythium spp. to QoI fungicides has not been investigated.

Stamina is labeled for use on alfalfa seed for managing Aphanomyces root rot and Phytophthora root rot as well as Fusarium spp. and Rhizoctonia solani. From the results of this study, Stamina would likely provide little control of seed rot and root rot caused by Pythium spp. when used on alfalfa seeds. Our results also suggest that Apron XL seed treatments may not be effective in controlling all strains of Pythium attacking alfalfa and that Fusarium spp. may be contributing to seed rot and damping-off. The effect of other fungicides on the Pythium and Fusarium pathogens causing seed rot and dampingoff of alfalfa warrants further investigation. The culture plate assay used and pathogens isolated in this study provide resources to screen candidate germplasm for resistance to seed rot and damping-off of alfalfa and for developing resistant cultivars.

\section{Acknowledgments}

We thank L. Radmer, B. Bucciarelli, and F. Breuillin-Sessoms for their assistance. J. Kurle and D. Malvick, University of Minnesota, kindly provided soybean pathogens. Funding was provided by the Minnesota Corn Research and Promotion Council, the Midwest Forage Association, and USDA-ARS-CRIS project 5062 12210-002D.

\section{Literature Cited}

Alejandro Rojas, J. A., Jacobs, J. L., Napieralski, S., Karaj, B., Bradley, C. A., Chase, T., Esker, P. D., Giesler, L. J., Jardine, D. J., Malvick, D. K., Markell, S. G., Nelson, B. D., Roberton, A. E., Rupe, J. C., Smith, D. L., Sweets, L. E., Tenuta, A. U., Wise, K. A., and Chilvers, M. I. 2017. Oomycete species associated with soybean seedlings in North America-Part I: Identification and pathogenicity characterization. Phytopathology 107:280-292.

Altier, N. A., and Thies, J. A. 1995. Identification of resistance to Pythium seedling diseases in alfalfa using a culture plate method. Plant Dis. 79:341-346.

Ariss, J. J., Rhodes, L. H., Sulc, R. M., and Hammond, R. B. 2007. Potato leafhopper injury and Fusarium crown rot effects on three alfalfa populations. Crop Sci. 47:1661-1671.

Bartlett, D. W., Clough, J. M., Godwin, J. R., Hall, A. A., Hamer, M., and ParrDobrzanski, B. 2002. Review: The strobilurin fungicides. Pest Manag. Sci. 58:649-662.

Brantner, J. R., and Windels, C. E. 1998. Variability in sensitivity to metalaxyl in vitro, pathogenicity, and control of Pythium spp. on sugar beet. Plant Dis. 82: 896-899.

Broders, K. D., Lipps, P. E., Paul, P. A., and Dorrance, A. E. 2007a. Characterization of Pythium spp. associated with corn and soybean seed and seedling disease in Ohio. Plant Dis. 91:727-735.

Broders, K. D., Lipps, P. E., Paul, P. A., and Dorrance, A. E. 2007b. Evaluation of Fusarium graminearum associated with corn and soybean seed ad seedling disease in Ohio. Plant Dis. 91:1155-1160.

Cook, R. H., and Zhang, B. X. 1985. Degrees of sensitivity to metalaxyl within the Pythium spp. pathogenic to wheat in the Pacific Northwest. Plant Dis. 69: 686-688.

Edmisten, K. L., Wolf, D. D., and Stromberg, E. L. 1988. Compatibility of metalaxyl with Rhizobium meliloti on alfalfa seed to control Pythium damping off. Crop Sci. 28:568-570.

Grau, C. R., Arny, D. C., and Nygaard, S. L. 1989. Assessment of alfalfa reaction to Anthracnose in controlled and field environments. Plant Dis. 73:167-170.

Hancock, J. G. 1983. Seedling diseases of alfalfa in California. Plant Dis. 67: 1203-1208.

Hancock, J. G. 1985. Fungal infection of feeder rootlets of alfalfa. Phytopathology 75:1112-1120. 
Hwang, S. F. 1988. Effects of VA mychorrhizae and metalaxyl on growth of alfalfa seedlings in soils from fields with "alfalfa sickness" in Alberta. Plant Dis. 72: 448-452.

Jones, C. R., and Samac, D. A. 1996. Biological control of fungi causing alfalfa seedling damping-off with a disease-suppressive strain of Streptomyces. Biol. Control 7:196-204.

Larkin, R. P., English, J. T., and Mihail, J. D. 1995. Effects of infection by Pythium spp. on root system morphology of alfalfa seedlings. Phytopathology 85 : 430-435.

Larkin, R. P., English, J. T., and Mihail, J. D. 1996. The relationship of infection by Pythium spp. to root system morphology of alfalfa seedlings in the field. Plant Dis. 80:281-285.

Leath, K. T., Erwin, D. C., and Griffin, G. D. 1988. Diseases and nematodes. Pages 621-670 in: Alfalfa and Alfalfa Improvement. A. A. Hanson, D. K. Barnes, and R. R. Hill, eds. ASA-CSSA-SSSA, Madison, WI.

Malvick, D. K., and Grau, C. R. 2015. Pythium seed and root rot. Pages 8-9 in: Compendium of Alfalfa Diseases and Pests, 3rd Ed. D. A. Samac, L. H. Rhodes, and W. O. Lamp, eds. American Phytopathological Society, St. Paul, MN.

Matsumoto, C., Kageyama, K., Suga, H., and Hyakumachi, M. 1999. Phylogenetic relationships of Pythium species based on ITS and 5.8S sequences of ribosomal DNA. Mycoscience 40:321-331.

Matthiesen, R. L., Ahmad, A. A., and Robertson, A. E. 2016. Temperature affects aggressiveness and fungicide sensitivity of four Pythium spp. that cause soybean and corn damping off in Iowa. Plant Dis. 100:583-591.

McLeod, A., Botha, W. J., Meitz, J. C., Spies, C. F. J., Tewoldemedhin, Y. T., and Mostert, L. 2009. Morphological and phylogenetic analyses of Pythium species in South Africa. Mycol. Res. 113:933-951.

Munkvold, G. P., and O'Mara, J. K. 2002. Laboratory and growth chamber evaluation of fungicidal seed treatments for maize seedling blight caused by Fusarium species. Plant Dis. 86:143-150.

O’Donnell, K., Humber, R. A., Geiser, D. M., Kang, S., Park, B., Robert, V. A. R. G., Crous, P. W., Johnson, P. R., Aoki, T., Rooney, A. P., and Rehner, S. A. 2012. Phylogenetic diversity of insecticolous fusaria inferred from multilocus DNA sequence data and their molecular identification via FUSARIUM-ID and Fusarium MLST. Mycologia 104:427-445.

O’Donnell, K., Kistler, H. C., Cigelnik, E., and Ploetz, R. C. 1998. Multiple evolutionary origins of the fungus causing Panama disease of banana: Concordant evidence from nuclear and mitochondrial gene genealogies. Proc. Natl. Acad. Sci. USA 95:2044-2049.

O’Donnell, K., Ward, T. J., Robert, V. A. R. G., Crous, P. W., Geiser, D. M., and Kang, S. 2015. DNA sequence-based identification of Fusarium: Current status and future directions. Phytoparasitica 43:583-595.

Parke, J. L., Rand, R. E., Joy, A. E., and King, E. B. 1991. Biological control of Pythium damping-off and Aphanomyces root rot of peas by application of Pseudomonas cepacia or P. fluorescens to seed. Plant Dis. 75:987-992.

Pegg, G. F., and Parry, D. W. 1983. Infection of lucerne (Medicago sativa) by Fusarium species. Ann. Appl. Bot. 103:45-55.

Radmer, L., Anderson, G., Malvick, D. M., Kurle, J. E., Rendahl, A., and Mallik, A. 2017. Pythium, Phytophthora, and Phytopythium spp. associated with soybean in Minnesota, their relative aggressiveness on soybean and corn, and their sensitivity to seed treatment fungicides. Plant Dis. 101:62-72.

Robideau, G. P., de Cock, A. W. A. M., Coffey, M. D., Voglmayr, H., Brouwer, H., Bala, K., Chitty, D. W., Désaulniers, N., Eggertson, Q. A., Gachon, C. M. M., Hu, C. H., Küpper, F. C., Rintoul, T. L., Sarhan, E., Verstappen, E. C. P., Zhang, Y., Bonants, P. J. M., Ristaino, J. B., and Lévesque, C. A. 2011. DNA barcoding of oomycetes with cytochrome $c$ oxidase subunit 1 and internal transcribed spacer Mol. Ecol. Resour. 11:1002-1011.

Schmithenner, A. F. 1964. Prevalence and virulence of Phytophthora Aphanomyces, Pythium, Rhizoctonia, and Fusarium isolated from diseased alfalfa seedlings. Phytopathology 54:1012-1018.

Schroeder, K. L., Martin, F. N., de Cock, A. W. A. M., Lévesque, C. A., Spies, C. F. J., Okubara, P. A., and Paulitz, T. C. 2013. Molecular detection and quantification of Pythium species: evolving taxonomy, new tools, and challenges. Plant Dis. 97:4-20.

Stelfox, D., and Williams, J. R. 1980. Pythium species in alfalfa fields in central Alberta. Can. Plant Dis. Surv. 60:35-36.

Taylor, R. J., Salas, B., Secor, G. A., Rivera, V., and Gudmestad, N. C. 2002 Sensitivity of North American isolates of Phytophthora erythroseptica and Pythium ultimum to mefenoxam (metalaxyl). Plant Dis. 86:797-802.

Uzuhashi, S., Tojo, M., and Kakishima, M. 2010. Phylogeny of the genus Pythium and description of new genera. Mycoscience 51:337-365.

Venancio, W. S., Rodrigues, M. A. T., Begliomini, E., and Souza, N. L. 2003 Physiological effects of strobilurin fungicides on plants. Agr. Sci. Eng. 9:59-68.

Zhang, B. Q., and Yang, X. B. 2000. Pathogenicity of Pythium populations from corn-soybean rotation fields. Plant Dis. 84:94-99. 